\title{
THE INFLUENCE OF EMOTIONALINTELLIGENCE AND ORGANIZATIONAL CITIZENSHIP BEHAVIOR TOWARDS OFFICER PERFORMANCE WITH THE ORGANIZATION AND RELIGIOSITY AS A MODERATING VARIABLE (STUDY ON THE EMPLOYEES OF THE EDUCATION AND CULTURE DEPARTMENT IN DEMAK)
}

\author{
Erika Bestyasamala*
}

\author{
* Affiliation: \\ Komisi Pemilihan Umum, \\ Demak, Indonesia
}

\begin{abstract}
:
Performance is always the problem faced by government organizations, so it is necessary to know the factors that affect the performance of employees. This research aims to test the influence of emotional intelligence and organizational citizenship behavior on employee performance with a moderated Climate organization and Religiosity in the service of education and culture of Demak Regency. This research uses a quantitative approach to Explanatory research. The population in this research is a Muslim employee perform duties in the service of education and culture of Kab. Demak and with a population of 117 people. The variable in this study consists of three free variables that is emotional intelligence (X 1), Organizational Climate (X 2), Religiosity (X 3) and two variable i.e. Organizational Citizenship Behavior (Y1) and the performance of the Employee (Y2). Data collection using a structured questionnaire tool is closed and the results of the data collection further analyzed by using Multiple Linear Regression equations model.

The research results showed that significant positive Emotional effect on performance, Organizational Citizenship Behavior significant negative effect on performance, emotional intelligence a significant positive effect against the performance of employees, Organizational Climate strengthens the influence of emotional intelligence on employee performance, Religiosity weakens the influence of emotional intelligence to increased Employee Performance, strengthen the influence of Religiosity Organizational Citizenship Behavior (OCB) against performance improvement Officer Office of education and culture of Demak Regency.

Keyword: Employee Performance, Emotional Intelligence, Organization Climate, Religiosity, Organizational Citizenship Behavior.
\end{abstract}




\section{INTRODUCTION}

Developments in Indonesia in the last few years led to the implementation of the Government's demands in accordance with the ideals of reform. The main goal of the reform of the bureaucracy of the Government bureaucracy is creating an Indonesia that is adaptive to the characteristics of professional, teamwork, high-performance, clean and free of corruption, Collusion and Nepotism, able to serve the public, neutral, prosperous, dedicated as well as holding fast to basic values and code of ethics State apparatus.

Human resources have significance because a role is active and dominant in any activity of the organization. In human organization serves as the determinant, the perpetrators and planners in achieving the objectives of the company and decide forward corporate pullback (Hasibuan, 2005). Employees are directed to improve the performance so that the being and behaving which reflect the responsibility, loyalty, and discipline. To achieve the best performance, the organization concerned conduct assessment of the implementation of the tasks generated by the employees in accordance with the prevailing system in the organization. Bernardin (2003) explains that "referring to notions of Performance as a result. In the context of the results, the performance is the result produced records (produced) over a specific job function or activity - activity during a given period“. Performance highlights for government organizations in articulating things - things that can be conducive to improved performance so that the creation of sustainable competitive advantage. Performance is always the problem faced by government organizations, so it is necessary to know the factors that affect the performance of employees. One measure of the performance of an employee is the intellectual ability, which is supported by the ability to master, manage yourself as well as the ability to build relationships with others (Martin, 2000).

Goleman (2000) stated. that to achieve success in the world of work is not only cognitive ability (cognitive intelligence) course needed but also the ability of emotional (emotional intelligence). And Ginanjar agustian (2005) argues that the existence of emotional intelligence, the better it will make employees showing better performance. The relationship between emotional intelligence against the performance of an employee described in research Fitriastuti Triana (2013) shows that emotional intelligence, Organizational Commitment, and Organizational Citizenship Behavior effect significantly to performance. But unlike the penelitianHari and Ahmad (2016) stated that Intellectual Intelligence (IQ) and emotional intelligence (EQ) no significant effect on performance while the spiritual intelligence (SQ) effect significantly.

Emotional intelligence can not only affect the achievement of the performance of the employees, but emotional intelligence can also affect organizational citizenship behavior (OCB) employees. OCB is the behavior of employees who exceed the demands of their job (Sego,1998). Karambayya (1989) have found the effect of OCB in the success of the organization. George (1996) believes the attention to the OCB in the organization is important when organizations are not able to predict accurately and widely varying behavior is needed and embody all the organization aims through the formal job description. Therefore, OCB can help your organization running effectively. Clément and Vandenberg (2000), suggested that the OCB provides more resources for the Organization and reduce the need for costly and formal mechanisms. If be correlated with OCB, it could be said that workers could effectively help 
and improve organization if carrying out responsibilities outside of assigned tasks in the job. With simple words, can tolerate the work is unpredictable and it is important for organizations.

The relationship between emotional intelligence and OCB described research Kanimozhi Narayanan (2016) that there is a high correlation between use of emotion with the OCB is directed at the organization. Employee performance can also be affected by external factors such as the climate of the organization. The climate of the organization is a picture that is public about the work of organizations that make up the atmosphere of hope and the feeling of the whole employees

so that the performance of employees on the rise. The climate of the organization affects the performance of employees by creating a healthy organizational climate. Thus, employees will

be more upbeat and expected to improve performance. The relationship between employee performance against Organizational Climate are explained in the studies of Naomi W, et al (2017) that there is a strong positive relationship between the independent variables and bound variables.

Religiosity is also one of the factors that can affect the performance of employees. The definition is relevant to the behavior of religion (religiosity) are hard to find. In several studies, often found the choice of a term or mention someone against religious or religious words. According to Jalaluddin Rakhmat (2004), the term religion refers to a belief in God that is always on, i.e. to the soul and the will of God that governs the universe and have moral relationships with human beings. So the attitude of religiosity in view Jaluluddin Rahmatmerupakan integration between religious knowledge, feelings and religious action inside a person. Human beings behave religiously because it is driven by the stimulus of punishment and reward. Mengindari punishment (torture) and expect the prize reward. Man is just a robot that moves mechanically according to administering punishment and rewards.

The relationship between Religiosity on employee performance described on the research of Novia Zahrah, et al (2016), results show that there is a significant relationship between Islamic religiosity on performance, as well as between Islamic work ethic on performance.

\section{LITERATURE REVIEW}

\section{Multicollinearity}

Multicollinearity test aimed at testing whether the regression model is found the existence of a correlation between free variables (independent). Good regression models should not happen the correlation between independent variables. To detect multicollinearity in the regression model is with a tolerance value and a variant of the Inflation Factor (VIF). Multikolinieritas the test results can be found at the following table 1. :

Table.1

Multicollinearity Test Result

\begin{tabular}{|l|l|c|c|}
\hline & \multicolumn{1}{|c|}{ Variabel } & Tolerance & VIF \\
Similatity 1 & Emotional Intelligence & 1,000 & 1,000 \\
Similarity 2 & Emotional Intelligence & 0,519 & 1,926 \\
& Organization Climete & 0,693 & 1,444 \\
& Religiosity & 0,772 & 1,296 \\
& Organizational Citizenship Behavior & 0,471 & 2,125 \\
\hline
\end{tabular}

Source :Output Testb Result, 2018 
Table 1, shows that the results of the calculation of the value of tolerance between the independent variables known to be independent variables in equations 1 and 2 have a value of tolerance is greater than 0.10 and the value of the Variance Inflation Factor (VIF) smaller than 10. The results show that there is no correlation between independent variables. The model regression 1 and 2, multicollinearity does not occur so that the regression model is feasible and can proceed to the next testing phase because it has met the assumption multicollinearity.

\section{heteroscedasticity}

Heteroscedasticity test aims to find out the same or no residual variance of the observation from one observation to another. The regression equation is that heteroscedasticity does not occur. Test heteroscedasticity analysis was done by looking at the graph scatter plot between $\mathrm{Z}$ prediction (ZPRED) which is the free variable ( $\mathrm{x}$-axis $=\mathrm{Y}$ yield prediction) and its residual (SRESID) which is a bound variable (axis $\mathrm{Y}=\mathrm{Y}$ predictions $-\mathrm{Y}$ real). Test heteroscedasticity more information can be seen in Figure 1 as follows:

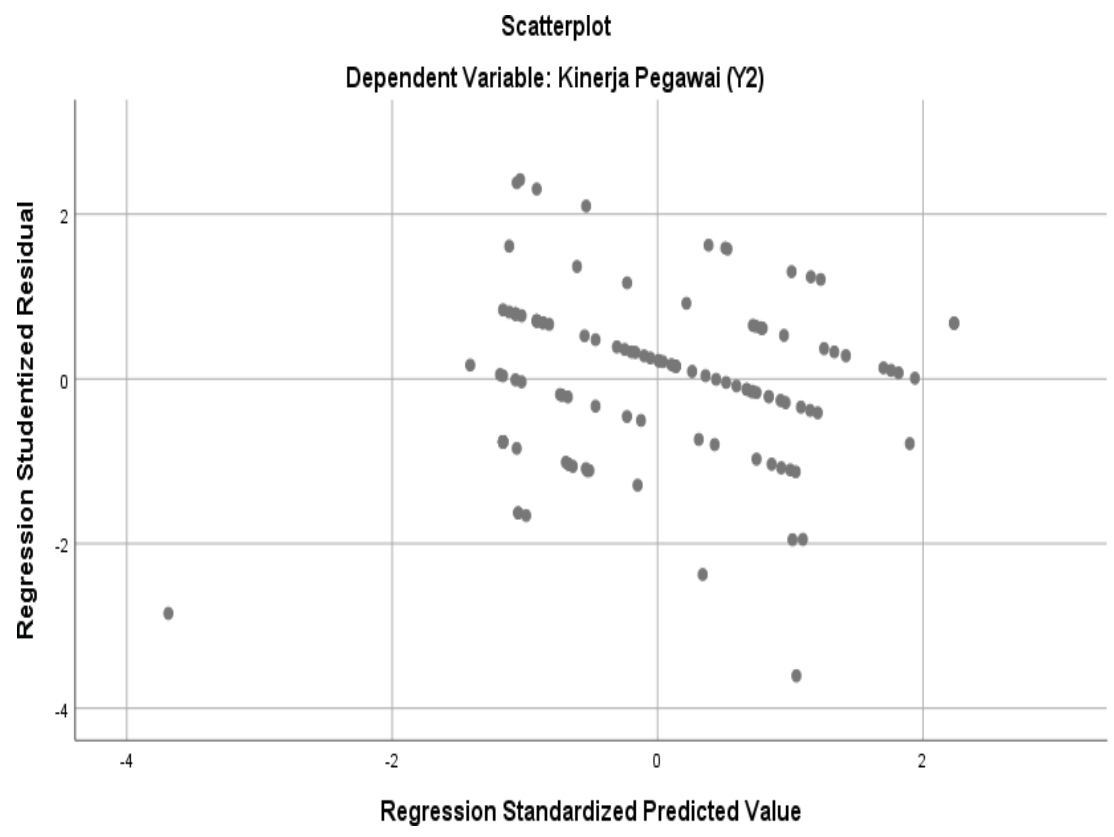

Source : Output Testb Result, 2018

Figure.

Heteroscedasticity Test Result

Test results from the heteroscedasticity using a scatterplot above-acquired points that spread below and above the Y-axis, and has no regular pattern, so it can be inferred that the variables of climate, emotional intelligence Organization, Organizational Citizenship Behavior, Religiosity and performance of Employees above do not occur or are heteroscedasticity homoscedasticity. 


\section{Multiple Linear Analysis}

The statistical analysis used in this study i.e., multiple linear regression. This analysis is used to find out the magnitude of the influence of emotional intelligence And Organizational Citizenship Behavior on employee performance with the climate of the Organization and Religiosity as a Moderating Variable calculation based on testing. multiple linear regression analysis can be obtained the following results,

Table

2

Regression Equation Model

\begin{tabular}{|c|c|c|c|}
\hline & Variable & $\begin{array}{l}\text { Standardized } \\
\text { Coefficient }\end{array}$ & t-count \\
\hline Emotional Intelligence (X1) & $\begin{array}{l}\text { Organizational Citizenship Behavior (Y1) } \\
\text { Employee Performance (Y2) }\end{array}$ & 0,671 & $9,7160,000^{*}$ \\
\hline Emotional Intelligence (X1) & & 3,380 & $2,5290,013^{*}$ \\
\hline $\begin{array}{l}\text { Organizational Citizenship } \\
\text { Behavior (Y1) }\end{array}$ & Employee Performance (Y2) & $-3,961$ & $-2,7610,007 *$ \\
\hline $\begin{array}{l}\text { Emotional Intelligence }(\mathrm{X} 1)^{*} \\
\text { Organization Climate }(\mathrm{X} 2)\end{array}$ & Employee Performance (Y2) & 0,527 & $3,5680,001 *$ \\
\hline $\begin{array}{l}\text { Emotional Intelligence (X1)* } \\
\text { Religiosity (X3) }\end{array}$ & Employee Performance (Y2) & $-6,642$ & $-2,6530,009 *$ \\
\hline $\begin{array}{l}\text { Organizational Citizenship } \\
\text { Behavior(Y1)* Religiosity (X3) }\end{array}$ & Employee Performance (Y2) & 6,929 & $2,7310,007 *$ \\
\hline F-count & $\begin{array}{l}\text { Equation } 1 \\
\text { Equation } 2 \\
\text { Equation } 1 \\
\text { Equation } 2\end{array}$ & $\begin{array}{r}94,407 \\
7,889 \\
0,451 \\
0,262\end{array}$ & \\
\hline
\end{tabular}

Source :Output Testb Result, 2018

Notes: * Significant Index: $5 \%$

\section{Emotional Intelligence Significantly Affected Employee Performance}

Influence of emotional intelligence test results on employee performance retrieved the value of the count of $t-2.529$ and significance of 0.013 . Therefore the value significance of $0.013(\alpha=0.05<5 \%)$, then Ho denied and H1 are accepted. It means that the emotional intelligence of significant positive effect on employee performance.

\section{Organizational Citizenship Behavior Significantly Affected Employee Performance}

The test results influence Organizational Citizenship Behavior on employee performance retrieved the value t-female registration-2.761 and significance of 0.007. Because of the significance of the value of $0.007(\alpha=0.05<5 \%)$, then Ho denied and H2 are received. This means that significant negative effect OCB on employee performance.

\section{Emotional Intelligence Significantly Affected Organizational Citizenship Behavior}

Influence of emotional intelligence test results against the Organizational Citizenship Behavior obtained a value of the t-count of 9.716 and significance of 0.000 . Because of the 
significance value of $0.000(\alpha=0.05<5 \%)$, then Ho denied and H3 are accepted. It means that the emotional intelligence of significant positive effect against the Organizational Citizenship Behavior.

\section{Organization Climate Strengthen The Influence of Emotinal Intelligence towards Employee Performance}

Influence of emotional intelligence test results against the performance of employees who moderated Climate variables the organization obtained a value of the t-count of 3.568 and significance of 0.001 . Because of the significance of the value of $0.001(\alpha=0.05<5 \%)$, then Ho denied and H4 are accepted. This means that the climate of the Organization strengthens the influence of emotional intelligence on employee performance.

\section{Religiosity Strengthen The Influence of Emotinal Intelligence towards Employee Performance}

Influence of emotional intelligence test results against the performance of employees who moderated the variable t-value acquired Religiosity count registration-2.653 and significance of 0.009 . Therefore the value significance of $0.009(\alpha=0.05<5 \%)$, then Ho denied and H5 are accepted. However, since t-count is negative so that mean Religiosity weakens the influence of emotional intelligence on employee performance.

\section{Religiosity Strengthen The Influence of Organizational Citizenship Behavior (OCB) towards Employee Performance}

The test results influence Organizational Citizenship Behavior on employee performance who moderated the variable t-value acquired Religiosity count of 2.731 and significance of Therefore the value of significance of $\alpha(0.050 .00<=5 \%)$, then Ho denied and H6 is received. This means that Religiosity influences Organizational strengthening Citizenship Behavior on employee performance.

\section{RESEARCH METHODOLOGY}

This type of research is the "Explanatory research" or research that is explained, it means this study emphasized relationships between variables research by testing his hypothesis contains the description but the focus located on the relationships between variables, (Singarimbun, 1989).

The population was determined in this study are all the employees at the Department of education and culture of Demak which amounted to 120 people. As for the sampling method using the census, which means that the number of samples of the same population. Of the total population of Muslim employees were selected because of the variable associated with religiosity in the broader perspective of Islam i.e. totaled 117 people.

The data used in the study was the primary data is the data that comes from the opinions of respondents are examined, in the form of written answers of the questionnaire, the results of observations against the object examined the test results. Primary data that will be excavated is the identity and perceptions of respondents about the variables of performance research 
officer, emotional intelligence, Organizational Citizenship Behavior, Organizational Climate, and Religiosity. The secondary data collected but not shown to a destination, for example, research interests, but also for any other purpose (Supomo, 2002). The data obtained from the articles, research journals, magazines, books that have to do with scientific research. While the Techniques of collecting data through a library study and dissemination of the questionnaire.

The variable in this study consists of employee performance, emotional intelligence, Organizational Citizenship Behavior, organizational climate, and religiosity. Can be seen on the basis of the following table:

\begin{tabular}{|c|c|c|c|}
\hline No & Variable & Indicator & Source \\
\hline 1 & Performance & $\begin{array}{ll}\text { a. } & \text { Performance Quality } \\
\text { b. } & \text { Performance Quantity } \\
\text { c. } & \text { Contribution in Organization } \\
\text { d. } & \text { Communication Quality }\end{array}$ & Robbins (2006) \\
\hline 2 & $\begin{array}{l}\text { Emotional } \\
\text { Intelligence }\end{array}$ & $\begin{array}{ll}\text { a. } & \text { Recognizing self emotions } \\
\text { b. } & \text { Managing emotions } \\
\text { c. } & \text { Self motivating } \\
\text { d. } & \text { Recognizing other's emotion } \\
\text { e. } & \text { Fostering relationship with others }\end{array}$ & Goleman (2002) \\
\hline 3 & $\begin{array}{l}\text { Organizational } \\
\text { Citizenship } \\
\text { Behavior (OCB) }\end{array}$ & $\begin{array}{ll}\text { a. } & \text { Compliance } \\
\text { b. } & \text { Helpful } \\
\text { c. } & \text { Kind-hearted and concern with society interest } \\
\text { d. } & \text { Sportive } \\
\text { e. } & \text { Kindness }\end{array}$ & Podsakoff, et al (2000) \\
\hline 4 & $\begin{array}{l}\text { Organization } \\
\text { Climate }\end{array}$ & $\begin{array}{ll}\text { a. } & \text { Structure } \\
\text { b. } & \text { Responsible } \\
\text { c. } & \text { Appreciation } \\
\text { d. } & \text { Risk } \\
\text { e. } & \text { Warmth } \\
\text { f. } & \text { Suppoty } \\
\text { g. } & \text { Performance standards } \\
\text { h. } & \text { Conflict } \\
\text { i. } & \text { Self Identity } \\
\end{array}$ & Litwin \& Stringer (1968) \\
\hline 5 & Religiosity & $\begin{array}{ll}\text { a. } & \text { Ideologic } \\
\text { b. } & \text { Ritual } \\
\text { c. } & \text { Intellectual } \\
\text { d. } & \text { Experience } \\
\text { e. } & \text { Consequence }\end{array}$ & Glok dan Stark (1965) \\
\hline
\end{tabular}

\section{RESULT AND DISCUSSION}

Emotional intelligence can explain the performance of Employees, with an indicator to recognize emotions, managing emotions, motivating oneself, recognizing emotions in others and build relationships with others. The indicator has an index score of the highest is fostering relationships with others on the category either. This indicates that the employee social are able to build a relationship with others, are able to read the situation and social networks carefully, interact smoothly, use this skill to influence, lead, military duty, complete the dispute, as well as working together in teams. This can support employees to work better, efficient and effective. Emotional intelligence and performance have a relationship and intertwined. Every individual in an organization that has a good emotion, tend to have a willingness to repair and improve 
its performance, as stated by Goleman (2000). These results support the Triana Fitriastuti (2013) stating that emotional intelligence, Organizational Commitment, and Organizational Citizenship Behavior significant effect on performance.

Organizational Citizenship Behavior cannot explain the performance of the employees, with the indicators of compliance, the nature of the good nature of the help, think of common interests, attitude and good sportsmanship. Indicators that have an index score is the lowest compliance. The results showed that employees of the Department of education and culture of Demak still a frequent violation of $46.15 \%$. This indicates that the employee does not meet the above minimum standard level required and still refers to the willingness of the individual in the exercise of duties and responsibilities. So, the effect on the low performance of the individual result is the goal of the organization is hampered. These results support the Lelei Joy et al., (2015) that has provided insight into the influence of altruism, manners, sportsmanship and citizenship on the performance of employees. Overall, the results showed no support for the hypothesis of the study. The attitude of sportsmanship, citizenship and the virtues of altruism, politeness is found to have a positive and significant influence on the performance of employees.

Emotional intelligence can explain the Organizational Citizenship Behavior. This indicates that emotional intelligence ability to represent people facing emotions. They define emotional intelligence as the ability to look up a person's feelings and also the feelings of others, which is part of the social and emotional intelligence, which can achieve the performance required of individuals who would direct citizenship behavior leads to the organization. Emotional intelligence refers to the ability to manage emotions that can contribute positively to the quality of social interaction that will affect the behavior of the domain of the Organization, as stated by Catherine s. Neal and David M. Ashkanasy (2005). These results support the Kanimozhi Narayanan (2016) stating that there is a high correlation between use of emotion with the OCB is directed at the Organization.

The climate of the Organization strengthens the emotional intelligence in explaining the performance of Employees, with the indicators of the structure, responsibility, rewards, Risks, warmth, support, performance standards, conflict, and Identity. Indicators that have an index score the highest is the warmth is on the category either. This indicates that tightly interpersonal relationships within the Department of education and culture of Demak who create an atmosphere of its own job depicting the atmosphere of work, friendship, and familiarity between employees. So that employees feel comfortable working environment that creates an atmosphere that brings him to achieve the activity properly, thereby providing energy or power for him to show optimal performance. These results support the Naomi W, et al (2017) that explains that there is a strong positive relationship between organizational climate and employee performance.

Religiosity weakens the emotional intelligence in explaining the performance of employees. Based on the results of research on indicators to recognize the emotions of other people there are answers of respondents who feel no/less able to read other people's emotions of $18.8 \%$ and who feel no/lacking attitude of empathy and being able to understand the feelings of another of $7.7 \%$. This indicates that employees do not have the ability to feel other people's perceived, understand the perspective of others and foster a relationship of mutual trust, and haven't been able to align 
themselves with the various types of relationships. In addition to the foregoing, religiosity weakens emotional intelligence on performance possible respondents could not interpret religion in depth (quality of religion). So, unconscious emotional level and still doing the activity that is prohibited by Allah SWT. Deviant behavior occurs as a result of which have an impact on the performance of individuals. This proves that Religiosity these results are inconsistent with Novia Zahrah, et al (2016), who explains that there is a significant relationship between Islamic religiosity on performance, as well as between Islamic work ethic on performance.

Religiosity strengthens Organizational Citizenship Behavior in explaining the performance of Employees, with indicator: Ideological, Intellectual, Rituals, experiences, and consequences. Indicators that have an index score of the highest is a consequence located on the category either. This indicates that officers behave is driven or affected by the teachings of Islam and synonymous with "a lot of Charity", which emphasizes the deeds of kindness as the embodiment of faith and worship in the form of real or manifestation the teaching of religion in the life of society. Like to help, giving charity, justice and prevent the devilry things. The results of the research of religiosity can strengthen the Organizational Citizenship Behavior in explaining the performance of employees. These results support the Novia Zahrah (2016), shows that there is a significant relationship between Islamic religiosity on performance, as well as between the work ethics of Islam against the performance of the work.

\section{CONCLUSION}

Emotional intelligence has a positive influence on performance direction employees of Department of education and culture of Demak. There was a significant positive relationship between emotional intelligence with the performance, where the higher emotional intelligence than the higher the performance of employees. This means that Every employee of the Department of education and culture of Demak who have emotions well, tend to have the will to improve and enhance the performance better, effectively and efficiently. Organizational Citizenship Behavior cannot explain the performance of the employees of the Department of education and culture of Demak there are a significant negative relationship between Organizational Citizenship Behavior with the performance, where the higher the OCB then the lower the performance of employees.

Emotional intelligence has a significant positive influence on Organizational Citizenship Behavior, where the higher emotional intelligence then the higher the OCB Climate Organization strengthen the influence of emotional intelligence on employee performance. That is, with moderated climate organization will strengthen the influence of the variables of emotional intelligence on employee performance Office of education and culture of Demak. Religiosity weakens the influence of emotional intelligence against the performance improvement officer Office of education and culture of Demak. Meaning, with moderated Religiosity, will weaken the influence of the emotional Intelligence against the variable the performance of employees. The influence of Organizational strengthening religiosity Citizenship Behavior (OCB) against performance improvement officer Office of education and culture of Demak. That is, with moderated religiosity will strengthen the influence of the variables of Organizational Citizenship Behavior (OCB) against the performance of employees. 


\section{REFERENCES}

Adams-Byers, J., Whitsell, S.S., \& Moon, S.M. (2004).Gifted students' perceptions of the academic and social/emotional effects of homogeneous and heterogeneous grouping. Gifted Child Quarterly, 48(1), 7-20

Aarons, G. A., \& Sawitzky, A. C. 2006.Organizational Culture and Climate and Mental Health Provider Attitudes Toward Evidence-Based Practice. Psychology Services, 3: 61-72.

Abdullah, Mas Udik. 2005. Meledakkan IESQ dengan Langkah Takwa dan Tawakal.Jakarta : Zikrul Hakim. Hal. 93

Agustian \& Ginanjar, A. 2005. Rahasia Sukses Membangun Kecerdasan Emosi dan Spiritual ESQ Emotional Spiritual Quotient. The ESQ Way 165, 1 Ihsan, 6 Rukun Iman dan 5 Rukun Islam. Jakarta: Penerbit Aga.

Aldag, R. \& Reschke, W. (1997). Employee value added: Measuring Discretionary Effort and its Value to the Organization. Center for Organization Effectiveness.

Al-Ghazali, 1992, Iman, Bidayah al-Hidayah, penterjemah Ahmad Zaini, Padang, Angkasa Raya, hal. 56.

Amin, Ahmad. 1997. Al-Akhlak. Penerjemah: Y. Bahtiar Affandi. Jakarta: Jembatan, hal. 77.

Anak Agung Inten Damaryanthi P.S \& Anak Agung Sagung Kartika Dewi. 2016. "Pengaruh Kecerdasan Emosional, Komitmen Organisasi, dan Organizational Citizenship Behavior Terhadap Kinerja Pegawai FEB.” E-Jurnal Manajemen Unud.Vol. 5.No. 2.Hal. 790 - 820.

Ancok, D. \& Suroso, F. N. 2005. Psikologi Islami: Solusi Islam Atas Problem- Problem Psikologi. Yogyakarta: Pustaka Pelajar. Hal. 73.

Anthony Dio Martin, (2000), Aplikasi EQ Based HR Management System, MajalahManajemen,No.148, Desember

Arikunto, Suharsimi. 2005. Pengelolaan Kelas dan Siswa Sebuah Pendekatan Evaluatif. Cetakan Keempat. Jakarta: PT. Raja Grafindo Persada

Asif, M., et al., 2011.An integrated management systems approach to corporate social responsibility, Journal of Cleaner Production (2011), doi:10.1016/j.jclepro.2011.10.034

Atkinson, T., Frechette, H. 2009.Creating A Positive Organizational Climate in A Negative Economic One: Improving Organizational Climate to Transform Performance. Forum, $1-3$

Badri, M. (1986).Dilema Psikolog Muslim, Terjemahan S.Z. Luxfiati, Jakarta:Pustaka Firdaus.

Bambang Supomo dan Nur Indriantoro, 2002, Metodologi Penelitian Bisnis. Cetakan Kedua, Yogyakara; Penerbit BFEE UGM.

Bar-On, R. 2000.Emotional and social intelligence: Insights from the Emotional Quotient Inventory (EQ-i). In R. Bar-On and J. D. A. Parker (Eds.), Handbook of emotional intelligence. San Francisco: Jossey-Bass. 
Bernardin, H. John. 2003. Human Resources Management: An Experiential Approach, 3rd edition, McGraw-Hill/Irwin, New York. pp. 143.

Bolino, M.C., Turnley, W.H., dan Bloodgood, J.M. ( 2002). -Citizenship Behavior and the Creation of Social Capital in Organizationl.Academy of Management Journal, Vol. 7, No. 4, 2002 pp. $502-522$

Boyatzis, R., Goleman, D \& Rhee, K. 2000. Clustering Competence In Emotional Intelligence:Insights From The Emotional Competence Inventory (ECI). In R. Bar-On and J.D.A. Parker (Eds.), Handbook of emotional intelligence. San Francisco: JosseyBass.

Castro, M. L. dan Martin, N. (2010).The relationship between organizational climate and employee satisfactions in a south Africa Information and technology organizations. SA Journal of Industrial Psychological, 36, 1-9.

Chen, X.P., Hui, C. \& Sego, D.J. 1998.The role of Organizational Citizenship Behavior in turnover: Conceptualization and preliminary tests of key hypotheses. Journal of Applied Psychology, 83, 922-931.

Clement, M., \& Vandenberghe, R. (2000). Teachers' professional development: A solitary or collegial (ad)venture?Teacher and Teaching Education,16, 81-101

Coleman S. James. 2008. Dasar-Dasar Teori Sosial. Nusa Media: Bandung

Cooper, Donald R dan Emory, C William, (1998). Metode Penelitian Bisnis. Edisi kelima. Jilid 1. Erlangga. Jakarta.

Dister, A. S. 1990.Pengalaman dan Motivasi Beragama. Yogyakarta: Kanisius, Hal. 10

Druskat, V. U., Sala, F. \& Mount, G. (2006).Linking emotional intelligence and performance at work: Current research Evidence with individuals and groups. Mahwah, NJ: Erlbaum.

Dyne, L., and Soon, A. 1998.Organizational Citizenship Behavior of Contingent Workers in Singapore. The Academy of Management Journal, Vol. 41, No. 6. Dec., 1998, 692-703

Farhan, M., and Niaz, A. (2012).Job Satisfaction as a Predictor of Organizational Citizenship Behavior A Study of Faculty Memb e rs a t Bu si n e ss Institutes. Interdisciplinary Journal of Contemporary Research In Business, Vol 3, No 9, 1447-1455.

Ferdiansyah, AP. 2016. "Pengaruh Kecerdasan Emosional Terhadap Kinerja Karyawan Melalui Organizational Citizenship Behavior pada Perusahaan Bersatu Sukses Group Surabaya." Jurnal Ilmu Manajemen. Volume 4. Nomor 2.Hal. 27 - 34.

Fisher, C.D. 2010 "Happiness at Work", International Journal of Management Reviews, Vol. 12 , Issue 4, 384-412.

George, J. M. (1996). Personality, affect, and behavior in groups. Journal of Applied Psychology, 75: $107-116$

Ghozali, Imam. 2005. Aplikasi Analisis Multivariate dengan SPSS. Semarang: Badan Penerbit UNDIP. 
Glock, C. \& Stark, R. 1966.Religion and Society In Tension. Chicago: University of California.

Goleman, D, 2000, Kecerdasan Emosi : Mengapa Emotional Intelligence Lebih Tinggi Daripada IQ, Alih Bahasa : T. Hermay, PT. Gramedia Pustaka Utama, Jakarta

Goleman, Daniel. 1998. What Makes a Leader? Harvard Business Review, 76 (6), 93-102.

Goleman, Daniel. 1995. Emotional Intelligence - Why It Can Matter More Than IQ. Bantam Books, the University of Michigan.

Goleman, Daniel. 2002. Kecerdasan Emosional (terjemahan). Jakarta: PT. Gramedia Pustaka Utama.

Golemen, D. 2000. Working With Emotional Intellegent. Jakarta: Gramedia Pustaka Utama.

Griffin, R. W. \& Moorhead, G. (2014).Organizational Behavior: Managing People and Organization, 11th Edition. Mason: Cengage Learning.

Gujarati, Damodar, 2003, Ekonometri Dasar. Terjemahan: Sumarno Zain, Jakarta: Erlangga.

Habibollah Salarzehi. 2011. "A Survey of Relationship Between Emotional Intelligence and Organizational Citizenship Behavior in Iran." International Business and Management. Vol. 3. No. 1. pp. 130-135.

Hari Nugroho Akimas dan Achmad Alim Bachri. 2016. "Pengaruh Kecerdasan Intelektual (IQ), Kecerdasan Emosional (EQ), Kecerdasan Spiritual (SQ) Terhadap Kinerja Pegawai Inspektorat Provinsi Kalimantan Selatan.” Jurnal Wawasan Manajemen. Vol. 4. Nomor 3.Hal. $259-271$.

Hasibuan, Malayu S.P. 2005. Manajemen Sumber Daya Manusia, Edisi Revisi. Bumi Aksara, Jakarta. Hal. 185.

Jalaluddin Rakhmat. 2004. Psikologi Agama: Sebuah Pengantar (Bandung: Mizan) hal. 50.

Kanimozhi Narayanan. 2016. "The Effect Of Emotional Intelligence On Organizational Citizenship Behavior." ASIAN JOURNAL OF MANAGEMENT RESEARCH. Volume 7. Issue 2. pp $154-169$.

Karambayya, R. (1989). Organizational citizenship behavior:Contextual predictors and organizational consequences. Un-published doctoral dissertation, Northwestern University, Evanston, IL

Katz, D. (1964). The motivational basis of organizational behavior. Behavioral Science,9, $131-133$.

Kiki Cahaya Setiawan. 2015. "Pengaruh Iklim Organisasi Terhadap Kinerja Karyawan Level Pelaksana Di Divisi Operasi PT. Pusri Palembang.” Jurnal Psikologi Islami. Vol. 1. No. 1. pp.23-32.

Kuncoro, Mudrajad. 2003. Metode Riset Untuk Bisnis \& Ekonomi. Jakarta: Erlangga. 
Lelei Joy Chelagat, Chepkwony, Protus Kiprop \& Ambrose Kemboi. 2015. "Effect of Organizational Citizenship Behavior on Employee Performance in Banking Sector, Nairobi County, Kenya." International Journal of Business, Humanities and Technology. Vol. 5.No. 4. pp 55 - 61.

Litwin GH, Stringer RA Jr. 1968. Motivation and organizational climate. Boston: Harvard University Press.

Luthans, Fred, 2007, "Perilaku Organisasi”, Terjemahaan, Yogyakarta : Andi

Mangkunegara, Anwar Prabu. 2010. Evaluasi Kinerja Sumber Daya Manusia. Jakarta: Refika Aditama.

Mariman Darto, Djoko Setyadi, Sukisno S. Riadi, Sugeng Hariyadi. 2015. "The Effect of Transformational Leadership, Religiosity, Job Satisfaction, and Organizational Culture on Organizational Citizenship Behavior and Employee Performance in the Regional Offices of National Institute of Public Administration, Republic of Indonesia. "European Journal of Business and Management. Vol.7. No.23. pp 205 - 219.

Martin, A. D. 2000. Kompetensi Model, Tren Baru Revitalisasi SDM. Jakarta: PT Refika Aditama.

Mathis, Robert L dan Jackson, John H. 2002. Manajemen Sumber Daya Manusia. Cetakan I, Edisi I. Graha Ilmu Yogyakarta.

Matthews, G., Zeidner, M. \& Roberts, R. D., 2002. Emotional Intelligence (Science and Myth). London: A Bradford Book The MIT Press. MTD Training, 2010. Emotional

Mayer, J. D.,DiPaolo, M. T., dan Salovey, P. 1990. Perceiving affective content in ambiguous visual stimuli: A component of emotional intelligence.Journal of Personality Assessment. Vol. 54. hal. 772-781.

Mohammad Kazem Bighami, Heshmat Khalife Soltani, Mitra Panahi, Farshid Abdi. 2013. "The relationship Between Emotional Intelligence and Organizational Citizenship Behavior (Testing the MediatingEffect of Job Satisfaction)." Organizational Behavior Studies Quarterly, Autumn. Vol. 2. No. 3. pp 178 - 195.

Naomi W. Githinji and Dr. Hazel Gachunga. 2017. "Influence Of Organizational Climate On Employee Performance In State Corporations In Kenya: A Case Of Kenya Industrial Estates Limited." Strategic Journals. Vol. 4, Iss. 2 (22), pp 376 - 395.

Novia Zahrah, Siti Norasyikin Binti Abdul Hamid, Shamsul Huda Binti Abdul Rani, Bidayatul Akmal Binti Mustafa Kamil. 2016. "The Relationship between Islamic Religiosity, Islamic Work Ethics and Job Performance." International Soft Science Conference. eISSN: 2357-1330. pp $710-716$.

Organ, D. W. 1988. Organizational Citizenship Behavior the Good Soldier Syndrome. Lexington, MA: Lexington book.

Phillips, J. J., 1999. Accountability In Human Resources Management. Massachusets: Butterworth-Heinemann. 
Podsakoff, P. M., Mackenzie, S. B., Paine, J. B., \& Bachrach, D. G. 1998. Some Positible antecedents of in role and extra role salesperson Performance. Journal of Marketing. 62: 87-98.

Podsakoff, P.M., MacKenzie, S.B., Paine, J.B. and Bachrach, D.G. 2000.“Organizational citizenship behaviors: a critical review of the theoretical and empirical literature andsuggestions for future research".Journal of Management.Vol. 26 No. 3.hal. 513-63.

Purba, Debora Eflina dan Ali Nina Liche Seniati. (2004) .Pengaruh Kepribadian Dan Komitmen Organisasi terhadap Organizational Citizenzhip Behavior," Makara Sosial Humaniora, Vol. 8, No.3, h.105-111.

Robbins, Stephen P. 2001. Perilaku Organisasi: Konsep, Kontroversi, Aplikasi, Jilid 1, Edisi 8, Prenhallindo, Jakarta

Robbins, Stephen P. Perilaku Organisasi. Edisi ke-10. Jakarta: PT. Indeks, 2006. Essentials of Organizational Behavior. Seventh edition. NewJersey: Prentice Hall, 2003

Safrilsyah, Rozumah Baharudin, Nurdeng Duraseh. 2010. "RELIGIUSITAS DALAM PERSPEKTIF ISLAM: Suatu Kajian Psikologi Agama.” SUBSTANTIA. Vol. 12. Nomor 2.Hal. 399 - 412.

Segal, J. 2000. Meningkatkan Kecerdasan Emosional. Jakarta: Citra Aksara. Hal. 27.

Singarimbun, Masri dan Sofian Effendi. 1989. Metode Penelitian Survey. LP3ES. Jakarta.

Stone, P., Mooney-Kane, C., Larson, E.L., Horan, T., Glance, L.G., Zwanziger, J., Dick, A.W., (2007).Nurse working conditions and patient safety outcomes. Medical Care, 45(6) : 571-587.

Thompson, Arthur Jr, dkk. 2005. Crafting and executing strategy. United States: McGraw-Hill

Thorndike, E. L. 1920. A constant error in psychological ratings. Journal of Applied Psychology. 4: 469-477

Thoules, Robert H (2000). Pengantar Psikologi Agama. Jakarta: Raja Grafindo Persada, Hal. 20

Triana Fitriastuti. 2013. "Pengaruh Kecerdasan Emosional, Komitmen Organisasional Dan Organizational Citizenship Behavior Terhadap Kinerja Karyawan.” Jurnal Dinamika Manajemen. Vol. 4. No. 2. pp: 103-114.

Tsai, Ming-Tien., Chun-Chen Huang. 2008. The Relationship among Ethical ClimateTypes, Facets of Job Satisfaction, and the Three Components of OrganizationalCommitment: A Study of Nursesin Taiwan. Journal of Business Ethics Vol.80, pp: 565-581.

Wong, C. S., Law, K. S. (2002). The effects of leader and follower emotional intelligence on Performance and attitude: An exploratory study. The Leadership Quarterly, 13, 243-274.

Wong, C. S., Wong, P. M \& Law, K. S. 2005. The interaction effect of emotional intelligence and emotional labor on job satisfaction: A test of Holland's classification of occupations. In C. E. J. Härtel, W. J. Zerbe, \& N. M. Ashkanasy (Eds.), Emotions in Organizational Behavior. Mahwah, NJ: Lawrence Erlbaum Associates, Inc. 